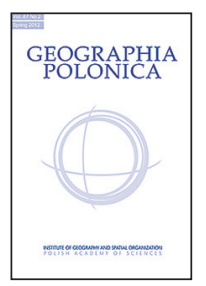

\title{
THE DIVERSITY OF TERRAIN AND LAND COVER IN POLAND
}

\section{Przemysław Śleszyński}

Institute of Geography and Spatial Organization

Polish Academy of Sciences

Twarda 51/55, 00-818 Warsaw: Poland

e-mail: psleszyn@twarda.pan.pl

\begin{abstract}
The map shows the diversity of the area surface of Poland in terms of its morphometry and land cover. Both SRTM-3 and Corine Land Cover (2006) satellite data were used. The transformation and combination of the contents of these two databases resulted in a classification of the landscape of Earth surface, especially in terms of physiognomy. The content of the map is an attempt to find a comprehensive and possibly synthetic solution, presenting the diversity of landscape. The data were arranged by communes, which has practical significance related to the assessment of these units for the purpose of spatial planning.
\end{abstract}

\section{Key words}

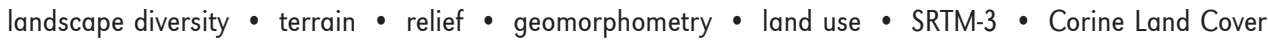
- Poland

\section{Conceptual and methodological assumptions}

The research on the relief and land cover, conducted for a long time, remains a prime subject of analyses. A decade ago, Pike (2002) collected information about more than 6,000 bibliographical items regarding geomorphology alone. In the recent years, the process of making available detailed satellite data regarding the diversity of relief and land cover of Earth surface, combined with the development of computer technology, made the analyses of this type a remarkably dynamically developing branch of knowledge. A comprehensive overview of the methods and indexes defining the morphometric diversity of land surface was presented by Shary et al. (2002), while on the subject of land use, a useful book is the textbook by Forman (1995). A range 
of analyses was performed for the area of Poland as well, including both the geomorphometric (Śleszyński 2013a) and land use diversity (Solon 2006; Łowicki \& Mizgajski 2013).

What is problematic in the evaluation and analysis of the landscape diversity is its high heterogeneity, due to which a large number of its individual elements must be taken into account. Despite the indubitable conceptual and methodological progress, there are still no satisfactory methods to present the diversity in a synthetic or comprehensive way, showing quantitatively the characteristics related to denivelations, the size of relief forms, and the land cover present there, similarly diversified in terms of the shape and nature of boundaries of various forms of land use. This subject is discussed, among others, by Solon (2003), who indicates that there is no consensus among the researchers in problematic terms, concerning the best, or for some reason most efficient approach (structural, dynamic, functional, etc.), even more so in the scope of delimitation of units to be analysed in terms of various traits attesting to the internal diversity of these units. One has to agree with the views arguing for using various approaches and units according to the needs.

In general, the relief and land cover form the basis for distinguishing the categories, classes, or types of landscape, particularly in its physiognomic aspect. Simultaneously, the relief is the basic determinant for the typology of natural landscape (Richling \& Dabrowski 1995). Whereas combining the elements of natural and anthropogenic environment gives grounds to distinguish the socalled architectural-landscape units (Bogdanowski 1989) or cultural landscapes (Degórski 2009; Myga-Piatek 2012). Prevalent in a vast majority of analyses is the method which assumes distinguishing the units in relation to the natural boundaries of forms, especially the land relief and then the land cover. Analyses using regular fields of reference, such as squares, are less common (Wyrzykowski 1991), and virtually non-existent for administrative units.
The proposed method is an attempt to combine the measures of the land relief and land cover diversity. The result is a classification of earth surface in terms of landscape. Obviously, it does not cover the whole complexity of biological environment which forms this landscape; still, it pertains to its most important structural traits constituting the 'frame' of the landscape, especially in the physiognomical aspect mentioned above. This is why it is particularly suited for practical purposes, particularly in the assessment of landscape diversity for the purposes of spatial planning and the monitoring of spatial governance and development (Martín Ramos \& Otero Pastor 2012; Śleszyński 2013b). This is why the commune was chosen as the basic unit of reference, as for various reasons it administrative boundaries cross various land formations and various categories of land cover.

Two sources of data were selected for analysis, both available to the public and most adequate for morphopetric analyses (SRTM3) as well as the analyses of land use (Corine Land Cover). In the former case, a thorough source technical characteristics of this data set for the construction of a digital terrain model was presented by Rodriguez et al. (2005). It is worth to supplement here that the mean error of measurement for the area of Poland is slightly greater than the assumed $1 \mathrm{~m}$ : in particular, in the case of areas with steeper slopes and in the rolling and hilly terrain it equals 2.7 m (Karwel \& Ewiak 2006). Moreover, the horizontal resolution for the latitude where Poland lies means a higher degree of latitudinal, and lower degree of longitudinal details. The horizontal resolution of publicly available files equals 3 " which for the area of Poland amounts to $60-65 \times 90 \mathrm{~m}$. For the purpose of the analysis, this was interpolated into a $>300 \times 300 \mathrm{~m}$ grid, resulting in a database for the area of Poland containing about $2.5 \mathrm{mln}$ altimetric points.

The land cover analyses used the Corine Land Cover database for 2006. What becomes visible in this case is the problem of the detail level of divisions which do not cover areas with buildings smaller than 25 ha or narrower than 
100 m. Gallego (2009) remarks that for 29\% of NUTS5 units in Europe, covering 16.6\% of its territory and $2.9 \%$ of population, the 'artificial surfaces' category is absent. This problem is of lesser importance for the territory of Poland, where a commune (NUTS5) is relatively large in terms of area compared to other European countries.

In the case of land relief, the standard deviation indicator was used. This results from the fact that this measurement shows the deviation from arithmetical mean, that is, how much all the measurements (of altitude in this case) differ from each other. In other words, the analysis of standard deviations provides the answer to the question what is the dispersion of values surrounding the mean and, thanks to this quality, well describes the variability of a given set. Therefore, it is useful in studying the degree of land relief diversity. The standard deviation indicator for reference fields in the form of a regular grid of hexagons for the territory of Poland was presented elsewhere (Śleszyński 2013a).

The analyses were performed using various computer software, mainly Global Mapper 9.0 (Global Mapper Software LLC) and Vertical Mapper (Maplnfo Corporation / Pitney Bowes, Inc.). The final edition of the map was done using Maplnfo Professional 9.0 software.

\section{Results}

The results of the analyses were presented on a map with a scale of $1: 2,500,000$. The values of the diversity indicators of relief and land cover were divided into 3 classes each. The

Table 1. Characteristic of communes by classes of relief and land cover

\begin{tabular}{|c|c|c|c|c|c|c|}
\hline Class* & $\begin{array}{l}\text { Number } \\
\text { of } \\
\text { entities }\end{array}$ & $\begin{array}{l}\text { Area } \\
\text { (thous. } \\
\text { sq. km) }\end{array}$ & $\begin{array}{l}\text { Popula- } \\
\text { tion } \\
\text { (thous.) }\end{array}$ & $\begin{array}{c}\text { Density } \\
\text { of population } \\
\text { (persons per } 1 \mathrm{sq} \cdot \mathrm{km})^{\star \star}\end{array}$ & $\begin{array}{c}\text { Standard } \\
\text { deviation } \\
\text { of denivelations }{ }^{\star \star}\end{array}$ & $\begin{array}{c}\text { Density of CLC } \\
\text { boundaries, level } 3 \\
(\mathrm{~km} \text { per } 100 \mathrm{sq} \cdot \mathrm{km})\end{array}$ \\
\hline A1 & 213 & 25.6 & 1,307 & 51 & 6.82 & 133.9 \\
\hline A2 & 175 & 21.4 & 1,058 & 49 & 7.41 & 215.3 \\
\hline A3 & 150 & 16.9 & 1,013 & 60 & 7.38 & 287.4 \\
\hline B1 & 238 & 39.4 & 1,505 & 38 & 14.20 & 147.6 \\
\hline B2 & 430 & 66.5 & 2,821 & 42 & 14.46 & 214.8 \\
\hline B3 & 263 & 30.4 & 1,661 & 55 & 14.01 & 286.8 \\
\hline C1 & 107 & 16.8 & 671 & 40 & 36.03 & 149.5 \\
\hline $\mathrm{C} 2$ & 274 & 41.7 & 2,036 & 49 & 40.07 & 215.6 \\
\hline $\mathrm{C} 3$ & 322 & 32.5 & 2,867 & 88 & 62.44 & 301.9 \\
\hline$M^{\star \star \star \star}$ & 900 & 21.6 & 23,270 & 1,079 & - & - \\
\hline Total & 3,072 & 312.7 & 38,209 & 122 & 22.07 & 238.0 \\
\hline
\end{tabular}

* Abbreviations: letters mark the assignment to a class according to the standard deviation of denivelation (in meters), and digits according to the CLC boundary density (Corine Land Cover, level 3; in kilometres per 100 square kilometres). Values: A - less than 10, B - 10 to 25, C - more than 25, 1 - less than 180, 2 - 180 to 250,3 - more than 250 .

** Indicator values calculated as non-weighted mean for all commune units in the class.

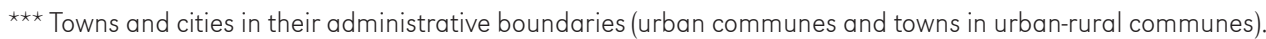
This category was not examined in terms of the values of diversity indicators but was included in the table for informational purpose. 
combination of both divisions results in a classification composed of 9 classes (Tab. 1).

The most represented class is B2, or the 'middle' class in the proposed classification. It amounted to 430 units (rural communes or rural areas in urban-rural communes) and encompassed $66,500 \mathrm{~km}^{2}$ of the country's area. The next most numerous class was C3 (322 units and $32,500 \mathrm{~km}^{2}$ ).

The most diverse relief and land cover ( $\mathrm{C} 3$ class) can be found in the communes in mountain (the Carpathian Mountains and Sudetes) and upland areas (the Świętokrzyskie Mountains, Lublin Upland, Krakow-Częstochowa Upland), and also in the Kashubia Lakeland. Interestingly, while the highest parts of the Polish mountains are characterised by high standard deviation values and slightly lower CLC boundary densities, which stems from them being less populated and having less transformed environment. In lowland areas, in turn, it is the eastern Mazovia and Podlachia (Podlasie) region which stand out in this respect. The higher CLC boundary density here is the result of historical conditions and the development of individual farming, which informed the greater patchwork of land use.

Somewhat 'opposite' to the C3 class is the A1 class, characterised by the lowest values of relief and land cover diversity. Communes belonging to this category are found mainly in Greater Poland, which is the result of its lowland landscape and larger, less fragmented agricultural holdings.

The content of the map was supplemented with population density. It is a determinant of land use, particularly in the suburban zones of the largest cities. Most interestingly, however, it does not translate directly to the increased CLC boundary density on the map.
This may be due to the insufficiently detailed division of the land cover map, as well as the presence of mixed classes in the CLC classification, which do not accurately reflect the boundaries between all the forms of land use. Therefore, it can be questioned how useful $\mathrm{CLC}$ is in the analyses of this type and if, perhaps, it might be necessary to have a more detailed land cover database at one's disposal for more specialised purposes.

The additional map with the scale of $1: 7,500,000$ presents the classification of relief and land cover diversity according to mezoregions. The same methodology and cartographic presentation method were used. The purpose of this map is to compare the analyses according to various units of reference, as well as to present the results and classifications in a more generalised form in terms of geographical scale.

Obviously, the proposed solutions do not exhaust all the possible ways of constructing the indicators and classifications (including typologies) of landscape diversity based on the relief and land cover. It seems that the proposed methodology can be developed further in several directions. First, it is possible to seek a greater number of indicators characterising the diversity of relief and land cover. Second, one may look for better individual indicators reflecting the diversity of relief and land cover in the best possible way. Third, it is important to indicate the level of data detail which is optimal for the needs and purposes, in particular in the area of land cover.

\section{Editors' note:}

Unless otherwise stated, the sources of tables and figures are the author(s), on the basis of their own research. 


\section{References}

BogDANOWSKI J., 1989. Metoda jednostek i wnętrz architektoniczno-krajobrazowych (JARK-WAK) w studiach i projektowaniu. Kraków: Politechnika Krakowska.

DegóRSKI M., 2009. Krajobraz jako odbicie przyrodniczych i antropogenicznych procesów zachodzqcych w megasystemie środowiska geograficznego. Problemy Ekologii Krajobrazu, 23, pp. 53-60.

FORMAN R., 1995. Land mosaics. The ecology of landscapes and regions. Cambridge: Cambridge University Press.

Gallego F.J., 2009. A Downscaled Population Density Map of the EU from Commune Data and Land Cover Information. Proceedings of the New Techniques and Technologies for Statistics seminar NTTS 2009, Brussels: Eurostat, http:// epp.eurostat.ec.europa.eu/portal/page/portal/ research_methodology/documents/S14P3_JAVIER_GALLEGO_DOWNSCALED_POPULATION_ DENSITY.pdf [21 October 2013].

KarWel A., EWIAK I., 2006. Ocena przydatności danych wysokościowych z misji SRTM do generowania NMT na obszarze Polski. Prace Instytutu Geodezji i Kartografii, vol. 52, no. 110, pp. 75-87.

ŁoWICKI D., MIZGAuskI A., 2013. Typology of physical-geographical regions in Poland in line with land-cover structure and its changes in the years 1990-2006. Geographia Polonica, vol. 86, no. 3, pp. 255-266.

Myga-Piątek U., 2012. Krajobraz kulturowy. Aspekty ewolucyjne i typologiczne. Katowice: Uniwersytet Śląski.

PIKE R.J., 2002. A bibliography of terrain modeling (geomorphometry). The quantitative representation of topography-supplement 4.0. Open-File Report 02-465, Washington: U.S. Geological Survey, http://geopubs.wr.usgs.gov/open-file/ of02-465/ [21 October 2013].
Martín Ramos B., Otero Pastor I., 2012. Mapping the visual landscape quality in Europe using physical attributes. Journal of Maps, vol. 8, no. 1, pp. 56-61.

RICHLING A., DĄBROWSKI A., 1995. Mapa typów krajobrazu naturalnego [in:] Atlas Rzeczypospolitej Polskiej. Warszawa: Główny Geodeta Kraju, Instytut Geografii i Przestrzennego Zagospodarowania PAN, Polskie Przedsiębiorstwo Wydawnictw Kartograficznych, map 53.1, scale 1:1,500,000.

Rodriguez E., Morris C.S., Belz J.E., Chapin E.C., Martin J.M., Daffer W., Hensley S., 2005. An assessment of the SRTM topographic products. Technical Report JPL D-31639. Pasadena: Jet Propulsion Laboratory, http://www2.jpl.nasa. gov/srtm/SRTM_D31639.pdf [21 October 2013].

Shary P.A., Sharaya L.S., Mitusov A.V., 2002. Fundamental quantitative methods of land surface analysis. Geoderma, vol. 107, no. 1-2, pp. 1-32.

Solon J., 2003, Ocena różnorodności krajobrazu na podstawie analizy struktury przestrzennej roślinności. Prace Geograficzne, 185, Warszawa: Instytut Geografii i Przestrzennego Zagospodarowania PAN.

Solon J., 2006. Granica mozaiki krajobrazowej a granica kulturowa [in:] J. Plit (ed.), Granice w krajobrazach kulturowych. Prace Komisji Krajobrazu Kulturowego PTG, 5, Warszawa: Komisja Krajobrazu Kulturowego PTG, pp. 64-71.

ŚLESZYŃSKI P., 2013a. A geomorphometric analysis of Poland based on the SRTM-3 data. Geographia Polonica, vol. 85, no. 4, pp. 45-59.

ŚLESzYŃSKI P. (ed.), 2013b. Wskaźniki zagospodarowania i ładu przestrzennego w gminach. Biuletyn KPZK PAN, 252, Warszawa: Komitet Przestrzennego Zagospodarowania Kraju PAN.

WYRZYKOWSKI J. (eds.), 1991. Ocena krajobrazu Polski $w$ aspekcie fizjonomicznym na potrzeby turystyki. Wrocław: Uniwersytet Wrocławski. Instytut Geograficzny. Zakład Geografii Regionalnej i Turystyki. 


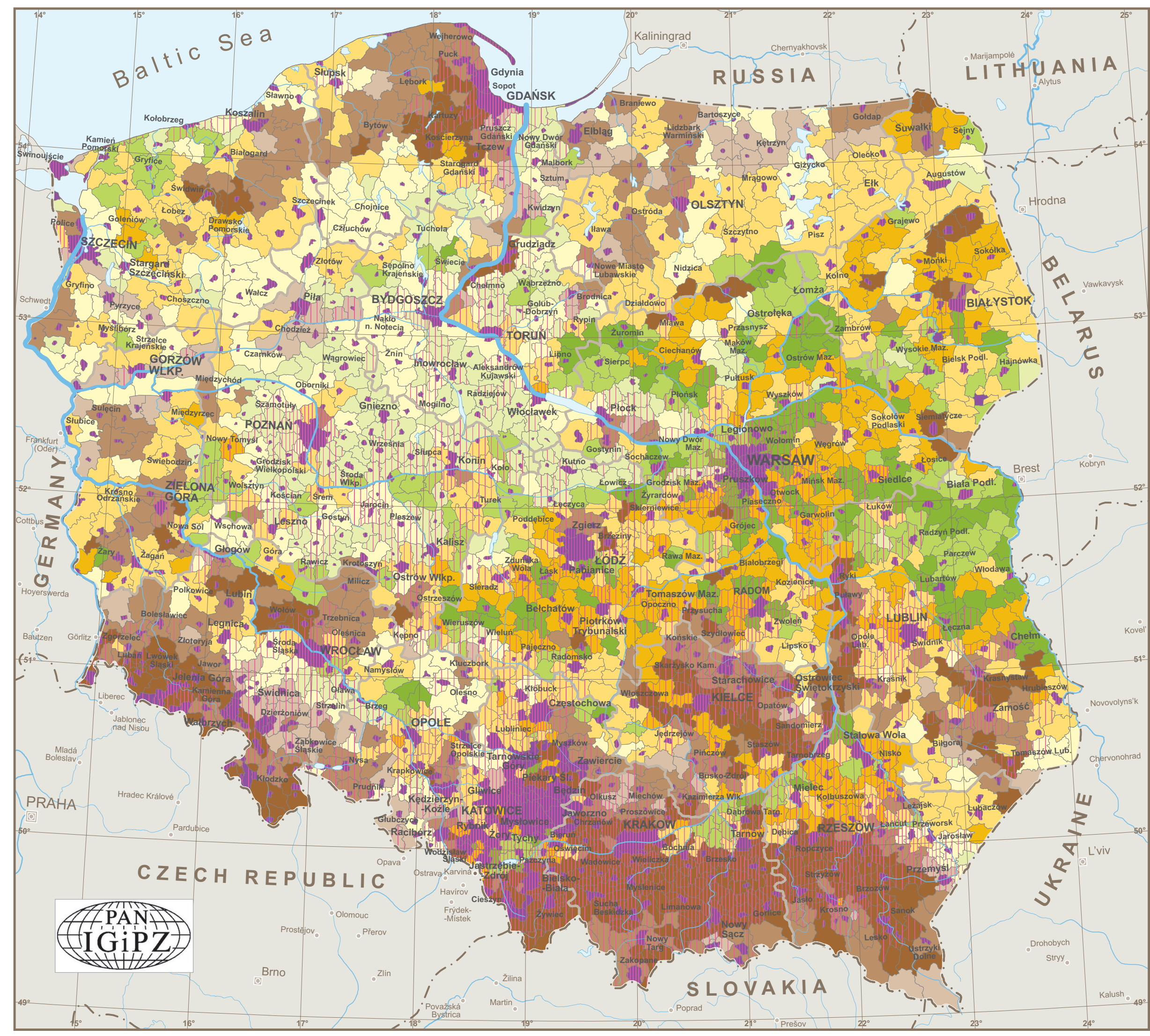

THE DIVERSITY OF TERRAIN AND LAND COVER IN POLAND by Przemysław Śleszyński

\begin{tabular}{|cccc} 
& Scale $1: 3,000,000$ \\
0 & 25 & 50 & 75 \\
\hline & 1 & $100 \mathrm{~km}$ \\
\hline
\end{tabular}

Diversity of relief and land cover

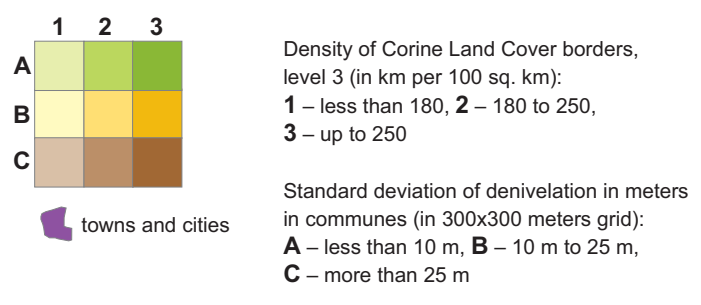

Density of population (2010)

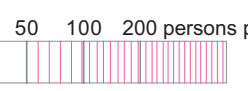

Diversity of relief

and land cover in mesoregions

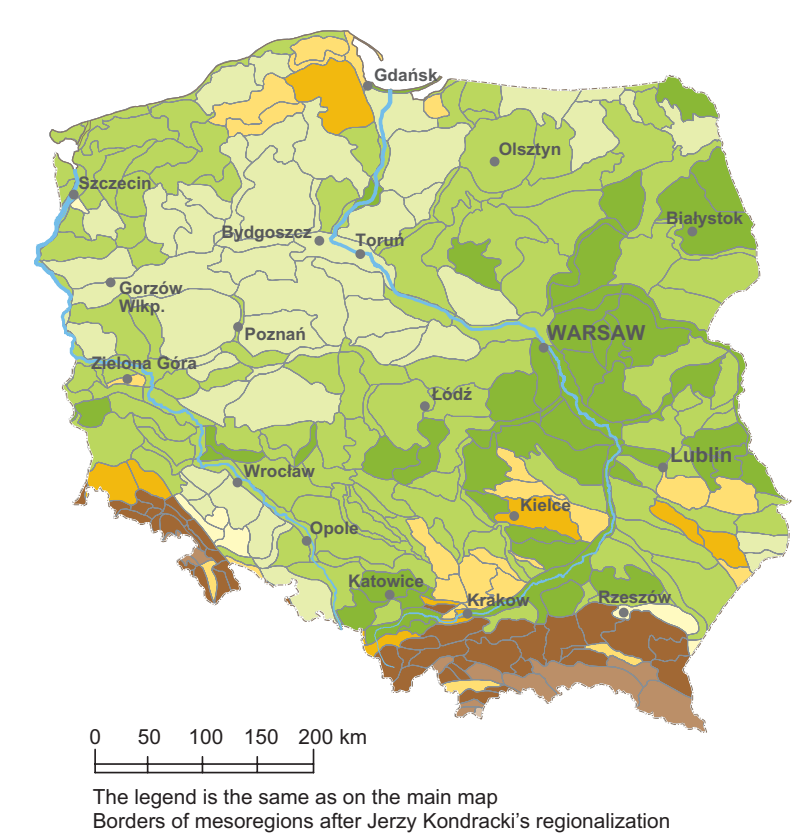

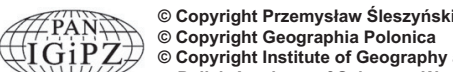

Cartography: Globe24.p.

To cite:
Slessynksi P, 2014. The diversity of terrain and
Geogyraphia Polonica, vol. 87, no. 3, pp. $481-486$ 
http://rcin.org.pl 